\title{
Flash floods simulation in a small drainage basin using HEC-RAS hydraulic model
}

\author{
Constantin Buta, Geanina Mihai and Mădălina Stănescu
}

\begin{abstract}
In recent years, climate conditions has caused extreme hydrological phenomena like flash floods that lead to significant material losses and impact on the environment in Dobrogea Region, Romania. In this context the needs for an integrated and sustainable approach to flash flood risk management even in small drainage basins are necessary, in order to reduce the the potential damages of flash floods in the future.

In this study the hydraulic models Hec-Ras and HecGeo-Ras were used in order to simulate the behaviour of the environment at the pressure of the flashfloods in a small drainage basin. The results were validated using the measurements undertaken after the flash-flood event recorded in October, 13th, 2015 as well as the data provided by the Corbu gauging station along time.
\end{abstract}

Keywords-Flash floods simulation, Hec-Ras, Hec-GeoRas.

\section{INTRODUCTION}

Intense rainfall events are the most common causal factor for flash flood formation. Flash flood is caused by heavy rainfall occurred in a short period of time, generally less than six hours.

This paper presents flash flood simulation using a hydraulic model created with the help of the HEC-RAS (Hydrological Engineering Centers - River Analysis System) software [3], [4], [5], in order to generate flooding limits for different flow rates on the Corbu Drainage Basin, (Dobrogea Region). These allow flood prone areas determination by overlapping the flood limits generated on different maps.

Manuscript received $5^{\text {th }}$ October 2017

Constantin Buta OvidiusUniversity of Constantza, Civil Engineering Faculty, Romania, (corresponding author phone: +40-241-619040; fax: +40-241-618372; e-mail:costibuta@yahoo.com)

Geanina Mihai - OvidiusUniversity of Constantza, Civil Engineering Faculty, Romania

Mădălina Stănescu - OvidiusUniversity of Constantza, Civil Engineering Faculty, Romania and S.C. SAM Proiect \& Management S.R.L. 
The Corbu Creek which drains a considerable part of Corbu locality (Constanta County) was used as a pilot drainage basin for the flash-flood simulation using the Hec-Ras program and the ArcGIS extension, HecGeo-Ras [6].

The flash-floods that occurred in the autumn of 2015 were used to validate the results of the simulation. A rare meteorological phenomenon occurred on October, $13^{\text {th }}, 2015$ in the area of Corbu locality, Constanta County. Meteorologists said it rained in 24 hours as much as it normally rains in a whole month, with 176 litres recorded per square metre. The flash flood blocked the road from Navodari to Corbu and 23 persons were rescued in the last minute by the emergency authorities after their vehicles were swept by the water. The major flash flood led to the evacuation of several Corbu locals. There was about $30-40$ flooded houses. For exemple, the water level in one of the houses was about $120 \mathrm{~cm}$. There were a few streets with approximately half a metre of mud which cannot be used. Two kilometres of the county road turned into a river flowing from the East to West. The large quantities of water accumulating from rainfall turned the road connecting the town of Navodari to Corbu into a river in a matter of minutes (Figure 1). The authorities said they have received the code amber warning when the water was already very high at Corbu.

The flash flood that occurred on the 13th of October 2015 in the Corbu Creek Catchment was a sudden and unexpected event making it difficult to implement flood mitigating/preventive measures according to EU Flood Directive.

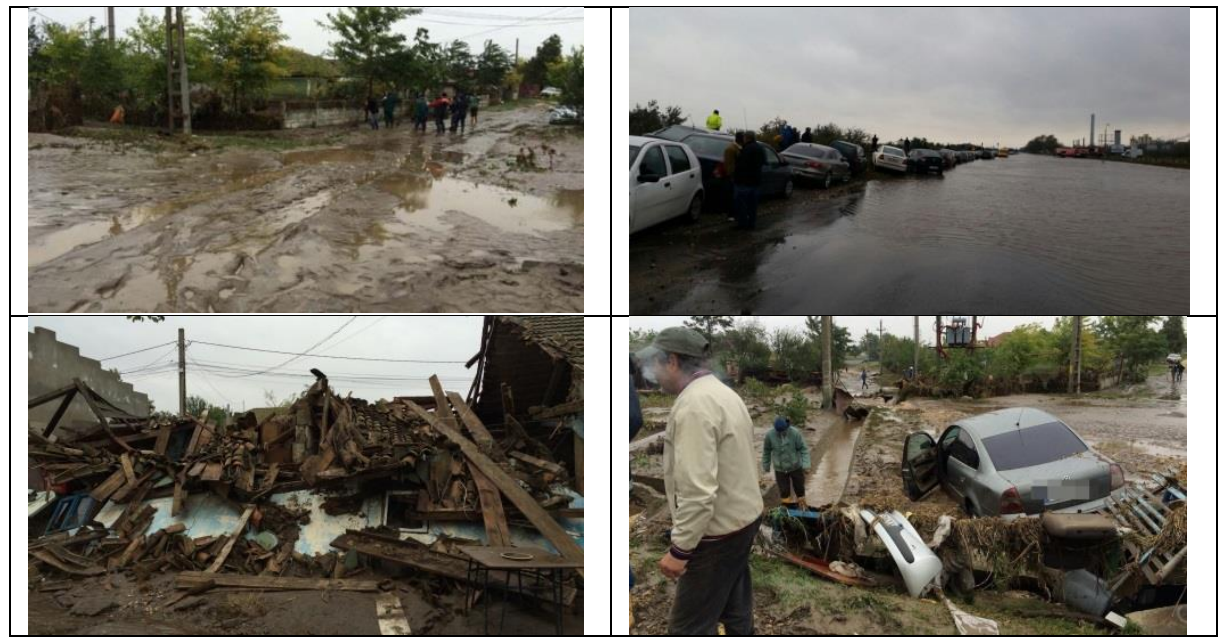

Fig. 1 Flash flood in Corbu locality

\section{METHODOLOGY AND DATA}

\subsection{The study area}

The Corbu drainage basin (Figure 2) is part of Dobrogea Littoral basin and was chosen as a pilot catchment for verifying the utility of the programs Hec-Ras and 
Ovidius University Annals Series: Civil Engineering, Issue19, $2017 \quad 103$

respectively, HecGeo-Ras. The drainage basin of Corbu creek is located in the area of Corbu locality in Constanta County and is situated at a distance of $23 \mathrm{~km}$ north of Constanta City. The Corbu locality consists of the following villages: Corbu, Vadu and Luminiţa. Corbu locality falls in the category of large rural municipalities with a population of over 5261 inhabitants. The surface of the Corbu District is about 11.804 ha and the administrative area stands at over 20.000 ha. The district territory is part of the Romanian Littoral area, being with a length of $6.2 \mathrm{~km}$ on the Black Sea Coast, with all the implications resulting from this, as a potential for development and protection of the natural environment. As a common land area, it occupies $151 \mathrm{~km}^{2}$. The profile of the Corbu locality is predominantly agricultural, but the development of the locality has been influenced by the industry and by the trends of the real estate market. Also, due to its geographical location between Mamaia Resort and Năvodari City to the south and the Danube Delta to the north (Fig. 2), the locality enjoys a great potential for tourism development. In this context, Corbu offers multiple leisure opportunities and diverse tourist attractions.

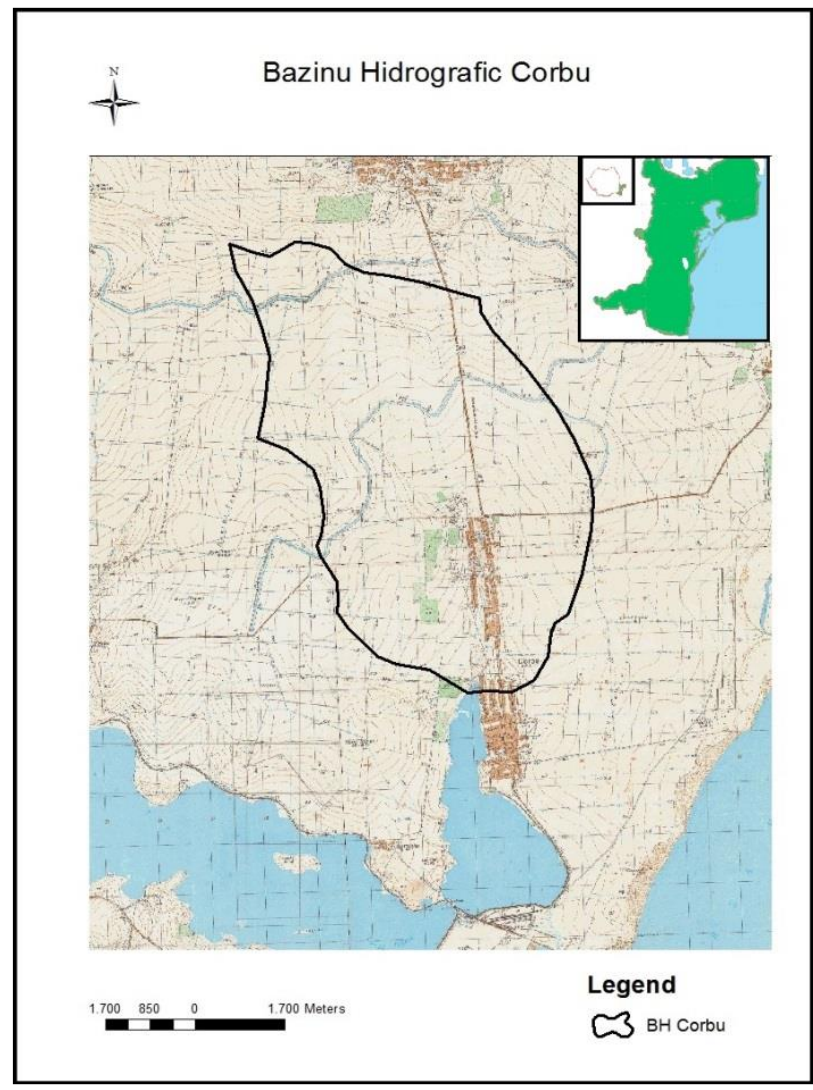

Fig.2 The Corbu drainage basin location 
The Corbu Drainage Basin is crossed by the Corbu Creek, which has a length of $7 \mathrm{~km}$, an annual average flow of $0.084 \mathrm{~m}^{3} / \mathrm{s}$ and discharges into Corbu Lake [7]. The main channel is normally dry but can have significant flows during heavily rainfall events like the entire hydrographical network from Dobrogea Region.

\subsection{Hydaulic modelling}

In the case of small drainage basins the time of response to heavy rain is very short (from 15 minutes to a few hours) making the use of hydrological modeling impossible.

In this study the Hec-Ras hydraulic model and HecGeo-Ras program were used in order to simulate the behaviour of the environment at the pressure of the flashfloods in a small-surface hydrological basins. It has to be mentioned the fact that the first problem addressed for this modelling programs was the accuracy in conditions of few variables known. The results were validated using the measurements undertaken immediately after the flash-floods recorded in October, 13th, 2015 as well as the data provided by the Corbu gauging station along time.

Hec-Ras is a geo-informational program, an integrated system of software capable to simulate the water flow in rivers and anthropic channels using a numerical model [3],[4],[5]. The program is one dimensional which means that there is no direct modelling of the hydraulic effects of the transversal profiles such as cross section forms and other aspects with bi- and tri-dimensional fluxes [3]. The Hec-Ras program was developed by the research group of Hydrologic Engineering Centre, part of the Institute for Water Resources, U.S. Army Corps of Engineers [3].

The HEC-GeoRAS program is an extension of the Hec-Ras developed by the cooperation between Hydrologic Research Engineering Center - HEC and Environmental Systems Research Institute - ESRI, helping with the pre- and postprocessing of the geometric date created in Hec-Ras [6].

The steady flow water surface profile is the most important component of HecRas for calculating the water surface profiles of a flash-flood event from the plain and plateau zone when the flow is not modified over time. Moreover, the water surface profiles calculation is based on the one dimensional energy equation [5]:

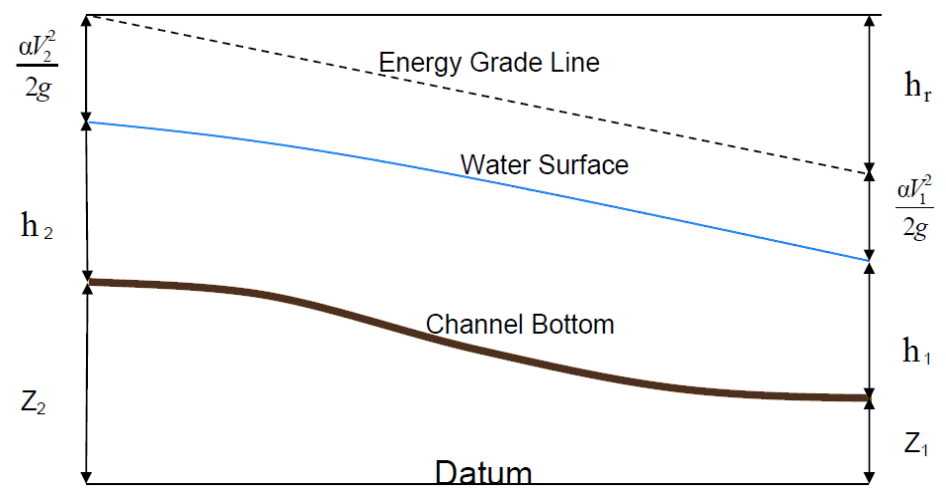

Fig. 3. Cross sectional representation of the energy equation 


$$
z_{1}+h_{1}+\frac{\alpha_{1} V_{1}^{2}}{2 g}=z_{2}+h_{2}+\frac{\alpha_{2} V_{2}^{2}}{2 g}+h_{r}
$$

where:

$\mathrm{z}_{1}, \mathrm{z}_{2}=$ elevation of the main channel inverts;

$\mathrm{h}_{1}, \mathrm{~h}_{2}=$ depth of water at cross sections;

$\mathrm{V}_{1}, \mathrm{~V}_{2}=$ average velocities (total discharge/total flow area);

$\alpha_{1}, \alpha_{2}=$ velocity weighting coefficients;

$\mathrm{g}=$ gravitational acceleration;

$\mathrm{h}_{\mathrm{r}}=$ energy head loss.

The energy head losses are evaluated through friction (using Manning equation, an empirical equation for gravitational flow) and expansion/compression (coefficient modified by the velocity) [3]

$\mathrm{h}_{\mathrm{r}}=\mathrm{LI}+\mathrm{c}\left|\frac{\alpha_{2} v_{2}^{2}}{2 g}-\frac{\alpha_{1} v_{1}^{2}}{2 g}\right|$

where:

$\mathrm{L}=$ weighted sector length;

$\mathrm{I}=$ the hydraulic gradient between the two sections;

$\mathrm{c}=$ coefficient of loss/recovery through expansion or contraction.

The working method used in HEC-RAS is to divide the discharge in the stream channel using the $\mathrm{n}$ values shown in the cross section, as a basis for quantization.

The flow is calculated for each cross section (left floodplain, channel and right floodplain) with the following relation from Manning's equation:

$V=C \sqrt{R * i}=\frac{1}{2} * R^{\frac{2}{3}} * i^{\frac{1}{2}}$

$Q=K_{i}^{\frac{1}{2}}=\frac{A * R^{\frac{2}{3}} * i^{\frac{1}{2}}}{n}$

where:

$\mathrm{K}=$ flow module;

$\mathrm{A}=$ area at cross sections;

$\mathrm{R}=$ hydraulic radius at cross sections;

$\mathrm{n}=$ Manning's roughness coefficient.

To obtain the flow module for that particular section, the program totals the flow modules for the right and left floodplains and for the channel. 
106 Ovidius University Annals Series: Civil Engineering, Issue19, 2017

The elevation of free surface of water in a cross section is determined by iteratively solving the energy equation and the head loss ratio.

Hec-Ras uses the geometric representations DEM's (Digital Elevation Model) and TIN's (Triangular Irregular Networks) making the rivers modeling easier and less expensive. Thereby, the combination of GIS extension with Hec-Ras represents the base for flood simulation and indeed, for water flow in rivers. Moreover, the program Hec-GeoRas is an extension of the basic program Hec-Ras and contains a suite of procedures, instruments and utilities for processing the geospatial information in ArcGIS [6]

The Corbu Drainage Basin is crossed by the Corbu Creek, which has a length of $7 \mathrm{~km}$ and an annual average flow of $0.084 \mathrm{~m} 3 / \mathrm{s}$ [7]. Field measurements were conducted to support the modelling process. The physio-geographical parameters, characteristics of the Corbu drainage basin are presented in the next table.

Table 1 Corbu drainage basin - the physio-geographical parameters

\begin{tabular}{|c|c|c|c|}
\hline Label & Symbol & Corbu Creekk & Units \\
\hline Drainage basin surface & $\mathrm{Fb}$ & 37,67 & $\mathrm{~km} 2$ \\
\hline Drainage basin perimeter & $\mathrm{P}$ & 24,6 & $\mathrm{~km}$ \\
\hline Shape coefficient (Gravelius) & $\mathrm{cf}$ & 1,13 & - \\
\hline Drainage basin average length & $\mathrm{Lb}$ & 9,15 & $\mathrm{~km}$ \\
\hline Drainage basin average wide & $\mathrm{B}$ & 4,12 & $\mathrm{~km}$ \\
\hline Stream Centerline length & $\mathrm{Lp}$ & 6,71 & $\mathrm{~km}$ \\
\hline Stream Centerline slope & $\mathrm{It}$ & 11,4 & $\mathrm{~m} / \mathrm{km}$ \\
\hline Drainage basin average slope & Imed & 1,49 & $\%$ \\
\hline Drainage basin average height & Hmed & 61,4 & $\mathrm{~m}$ \\
\hline
\end{tabular}

Based on the hydrological recorded data, the average annual flows, minimum and maximum annual flows for the Corbu gauging station were plotted as follows:

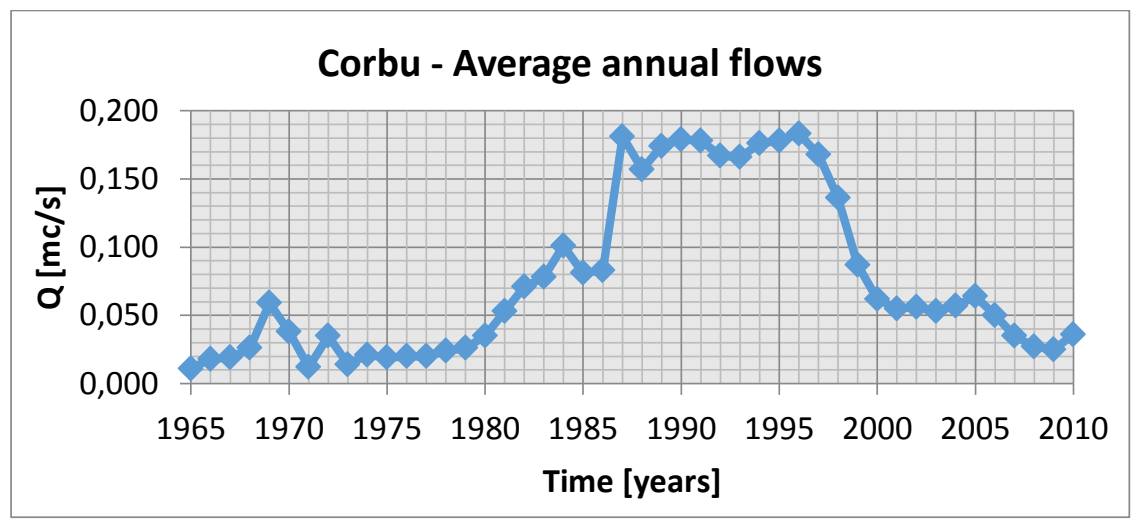




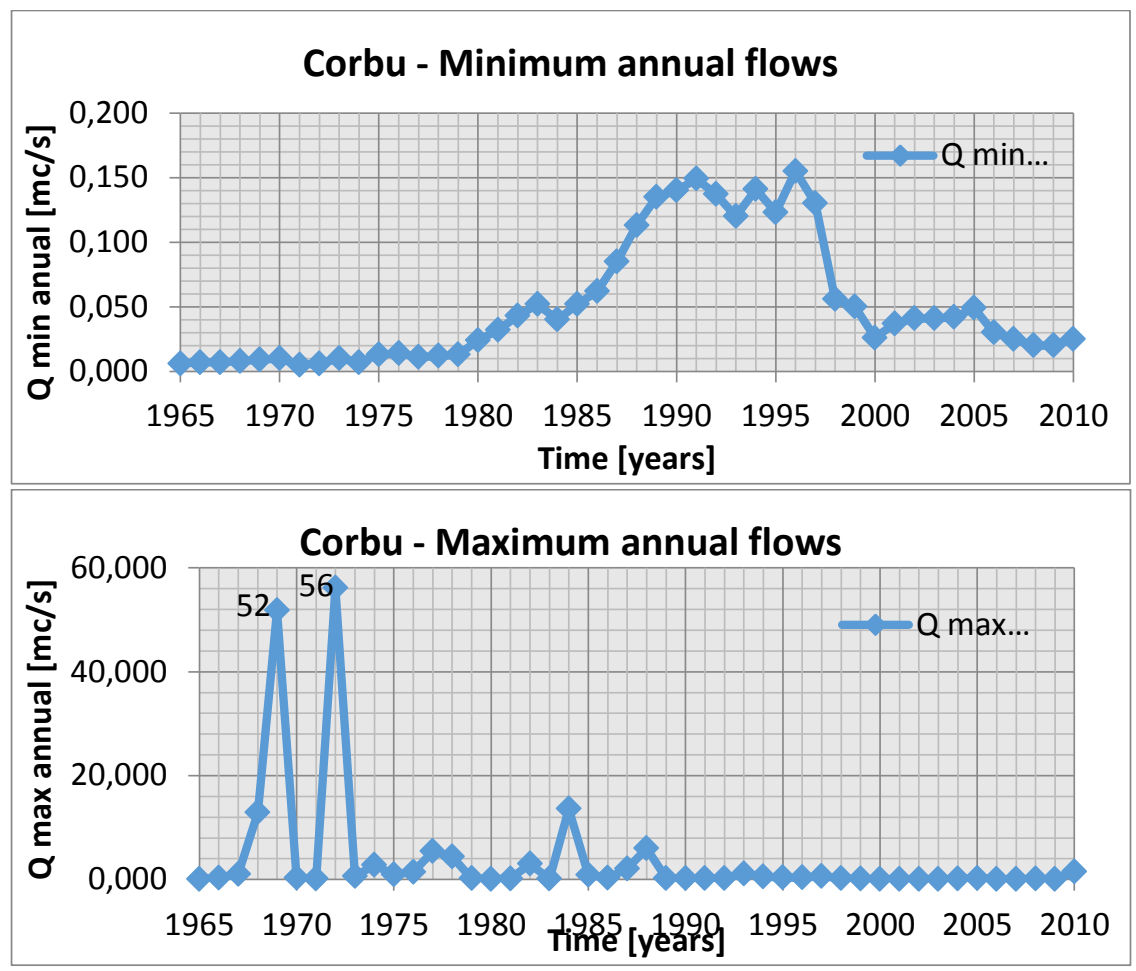

Fig. 4: Annual recorded flows data

The discharges with different exceeding probabilities used for flash flood-prone area mapping were obtained based on the frequency analysis of annual flood peaks between 1965 and 2015 at the Corbu gauging station.

Pearson III distribution function was selected to calculate the maximum discharge with different return periods. [12].

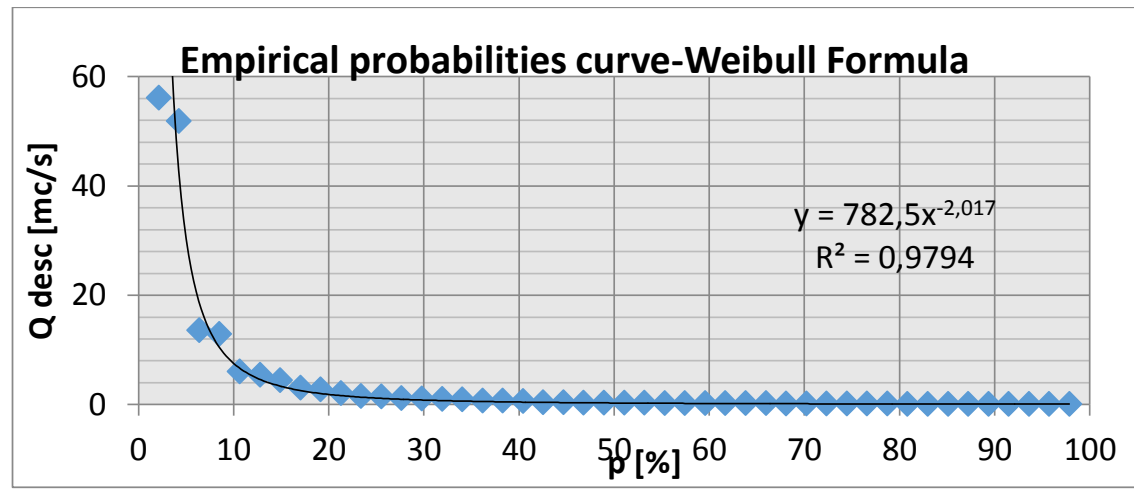

Fig. 5: Empirical probabilities (Weibull formula) 
According to EU Flood Directive [10], the exceedance probabilities (P\%) of $0,1 \%, 0,5 \%, 1 \%$ and $2 \%$, corresponding to return periods of $1000,500,100$ and 50 years respectively, were considered.

The discharges with different probabilities were obtained using NIHWM's Methodology (National Institute of Hydrology and Water Mangement) [12]. The rootmean-square error (RMSE), which expresses the difference between the values estimated by Pearson type III distribution and the ones estimated based on the empirical curve (using the Weibull formula), has the lowest values, and the theoretical curve best fits empirical probabilities determined based on the measured values (figure 6).

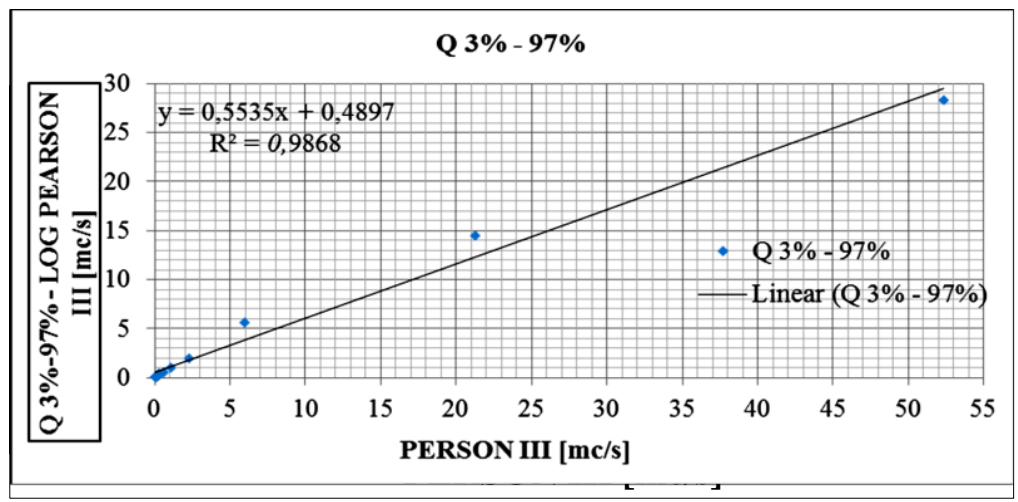

Fig. 6: Pearson III theoretical distribution curve

Using these data and the Log Pearson Type III probability distribution function, flood discharges matching a maximum of 50,100, 500 and 1000-year return intervals have been calculated [7], [8]. The flood peaks for exceedance probabilities are: $\mathbf{3 3 6 . 4}$ $\mathrm{m} 3 / \mathrm{s}$ for P $0,1 \%$ (1000 years return period), $\mathbf{2 3 8 , 6} \mathrm{m} 3 / \mathrm{s}$ for P $0,5 \%, \mathbf{1 9 5 , 6} \mathrm{m} 3 / \mathrm{s}$ for $\mathrm{P}$ $1 \%$, and $\mathbf{1 5 4 , 5} \mathrm{m} 3 / \mathrm{s}$ for $\mathrm{P} 2 \%$.

The flood discharges calculated and the quantified geometric data were transferred to the hydraulic model and subjected to a flash flood simulation.

As a result of the hydraulic analysis, digitised maps showing the spread of the floods and maximum water levels for the 50, 100, 500and 1000-year return intervals were prepared [11].

\subsection{Case study-flash flood simulation}

Using HEC-RAS hydraulic model and ArcGIS software the flash-flood simulation for the Corbu drainage basin can be structured in three important steps including [2]:

- the DEM preparation in ArcGIS 10.1 software,

- the pre-processing of geometric data in Hec-GeoRas,

- the post-processing of data information in Hec-Ras and the flood simulation. 
In the first step, the Digital Terrain Model (DTM) has been performed using topographical maps by digitizing the contour lines and the known elevation points. The digital terrain model was obtained from elevation information shown on topographic base maps published by the Romanian Military Geographic Institute at $1: 25,000$ scale [1].
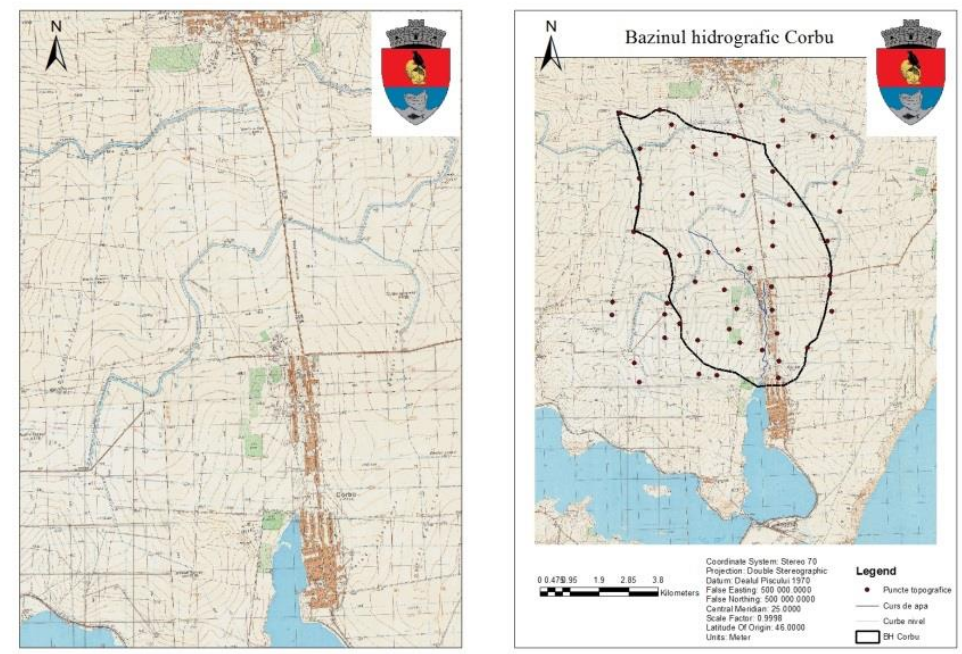

Fig.7 Topographical Map (1:25000)-left and Corbu drainage basin delineation-right

In order to compute river's cross sections in HEC-RAS model we should first provide TIN (Triangulated Irregular Network) plan of the area in geographical information system (GIS), and then with help of Hec-GeoRas software which has linked to ArcGIS software, we should determine the lines of river and its banks and we should also extract all cross sections. The model was created using the Triangulated Irregular Network.

In the application the drainage network was extracted automatically using the DEM, because digitizing it manually from the $25 \mathrm{k}$ maps would have generated important errors. The accuracy of the network is even higher because of the high resolution of the DEM, along with its capability to generate the temporary drainage network [1].

The mapping of the stream network, via the creation of a flow accumulation grid, (Fig. 9), can be useful in the creation of the main channel (stream centreline) of Corbu creek.

The geometric data (e.g. stream centerline, banks, flow path centerline and cross-sections, etc.) were extracted from the DEM and used in the analysis.

The second step was the creation with HEC-GeoRAS of RAS layers which were used for geometric data development. 


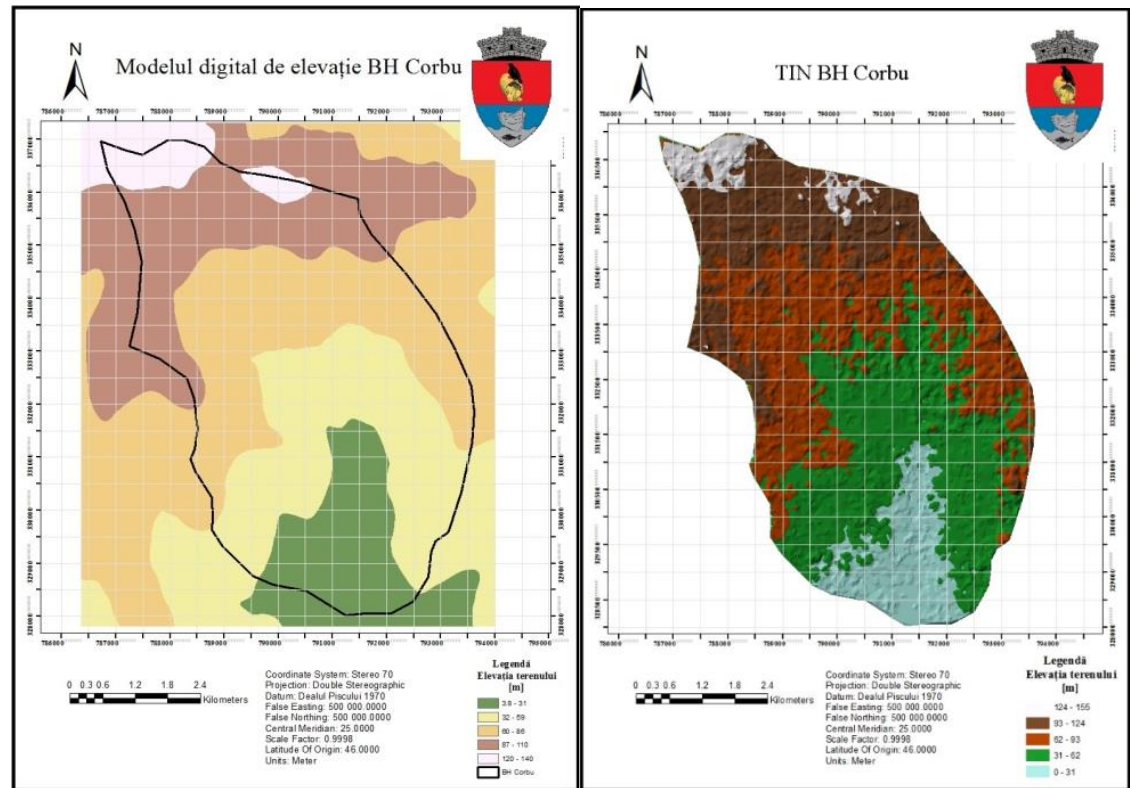

Fig. 8 Digital Terrain Model (DTM) - left and Triangulated Irregular Network (TIN) -right for Corbu drainage basin

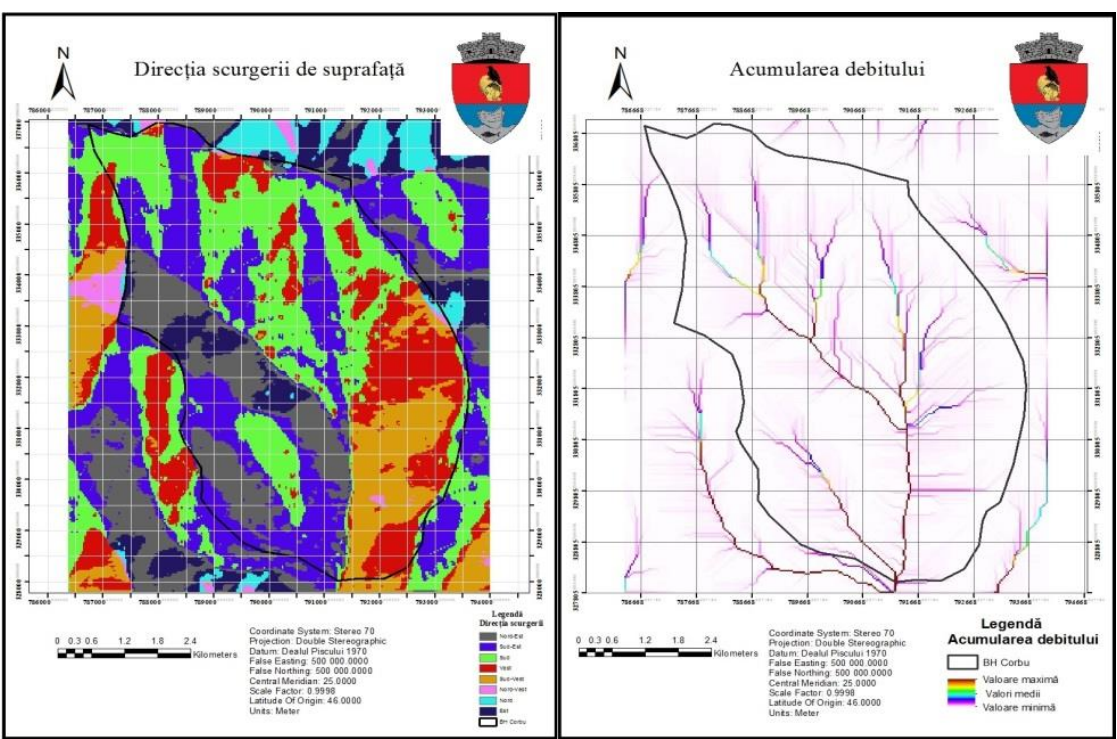

Fig. 9 Flow direction - left and drainage network - right for Corbu drainage basin 


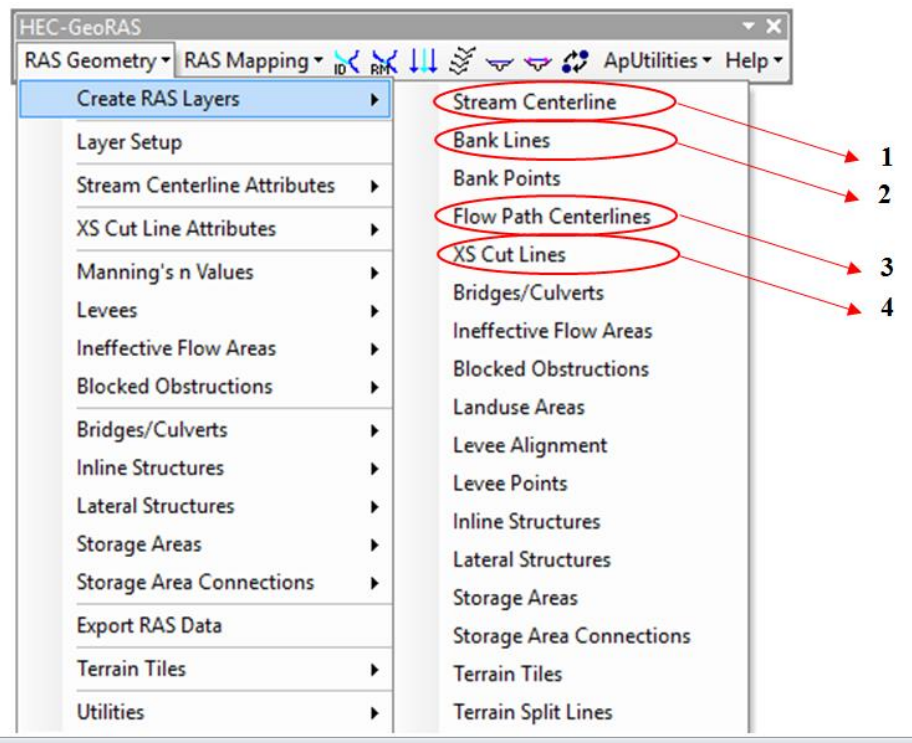

Fig. 10. The principal geometric data layers (1.Stream Centerline, 2.Bank Lines, 3. Flow Path Centerline and 4. XS Cut Lines)

The data were automatically saved in a geo-database and represented the base for the hydraulic analyse in Hec-Ras. The principal layers used are presented in the following sections.

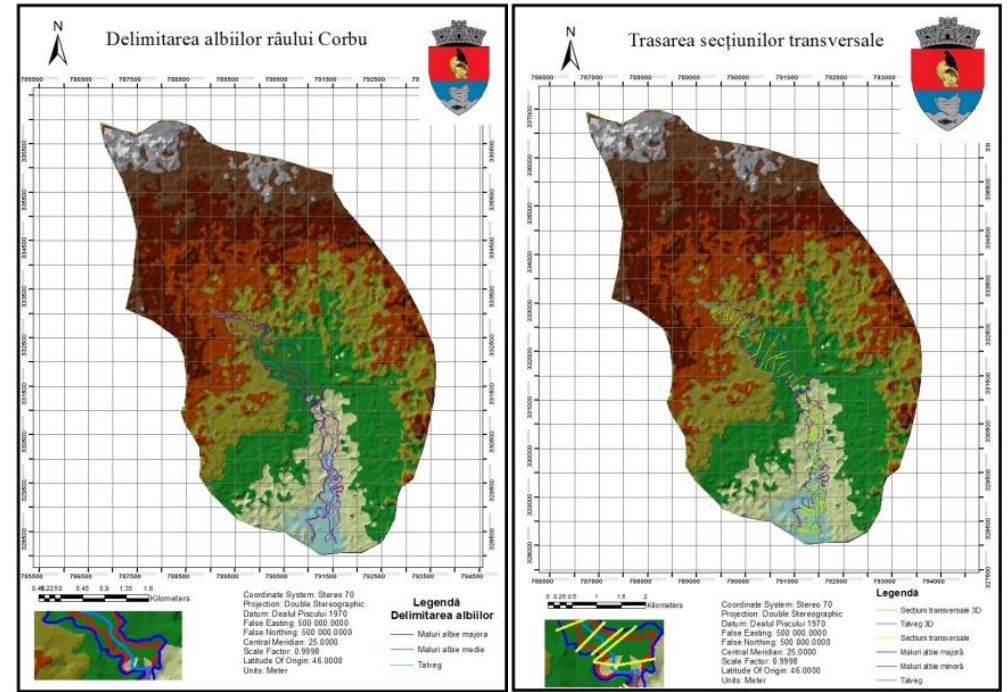

Fig. 11. The Stream Centerline, Banks (left) and the Cross Section Cuts Lines/ XS Cut Lines (right) 
The Stream Centerline layer was used for digitizing the Corbu creek and its tributaries using lines; for each vector a name was given and the digitization was done from upstream to downstream.

The Main Channel Banks helped to demark the floodplain using lines which intersect the transversal profiles.

The Flow Path Centreline is used to create different types of lines which will indicate the extension of the river water.

The Cross Sections (XS Cut Lines) were used to create the transversal profile, perpendicular on the flow direction which covered the entire floodplain. Although the $\mathrm{XS}$ cut lines can be generated automatically with an equal distance between them and afterwards corrected carefully, in this study they were manually created.

Initially, the cross sections had only XY coordinates while the $\mathrm{Z}$ coordinate was automatically extracted from the DEM, and the profile becoming 3D.

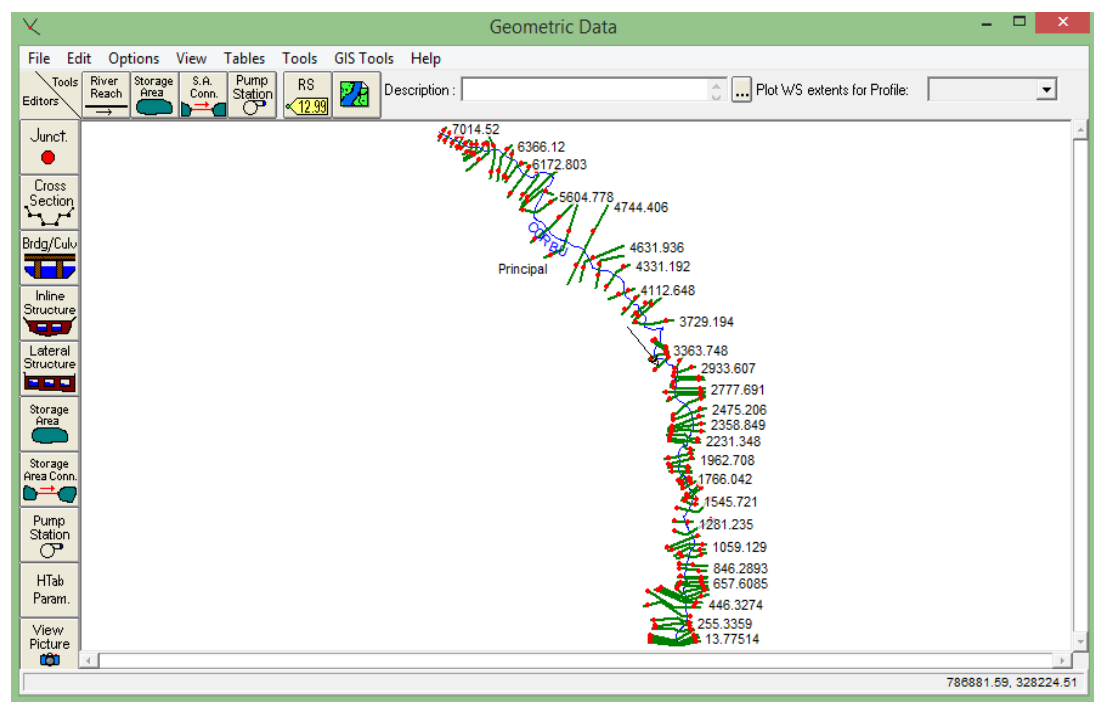

Fig. 12. The Stream Centerline, Banks (left) and the Cross Section Cuts Lines/ XS Cut Lines (right)

In the third step, after determining the stream centerline and right and left banks, the created cross sections in GIS has transformed to output and then has been called in HEC-RAS software.

What is more, each cross sections corresponds with a land-use category and has an $\mathrm{N}$-value, known as the Manning value or the roughness value which depends on the surface roughness, vegetation, channel irregularities and dimension, etc. 


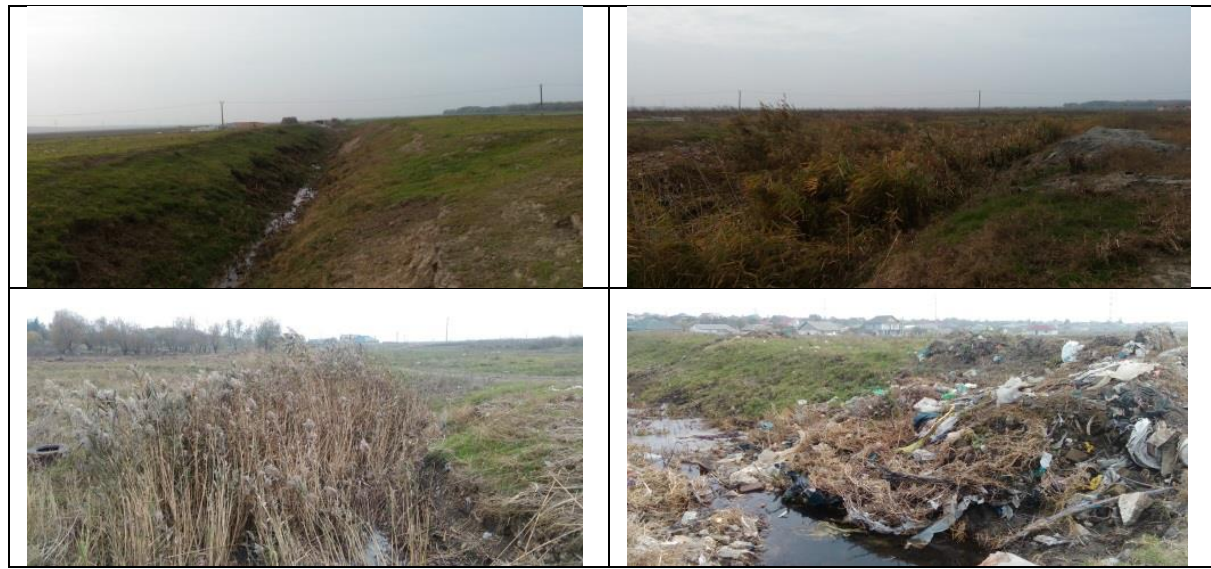

Fig. 13. Surface roughness, vegetation, channel irregularities and dimension

The information for land-use, surface roughness, and channel irregularities were obtained through field measurements and observations.

The Figure 13 shows the categories of land-use in the Corbu drainage basin where a considerable part is covered by agriculture land (the lowest Manning values) which acts without any obstruction in the flash floods way and enhances the flood speed while the cross sections covered by vegetation and obstruction (the highest Manning values) allows the water extension in the floodplain..

Roughness coefficients were assigned manually for each cross sections, according to different land cover types.

\begin{tabular}{|c|c|c|c|c|c|}
\hline \multicolumn{6}{|c|}{ Edit Manning's $n$ or k Values } \\
\hline \multirow{2}{*}{ 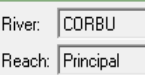 } & \multicolumn{3}{|c|}{ 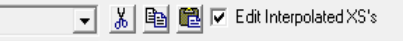 } & \multirow{2}{*}{$\begin{array}{c}\text { Channel } n \text { Values have } \\
\text { a light green } \\
\text { background }\end{array}$} & \\
\hline & $\nabla$ All & Regions & $\nabla$ & & \\
\hline \multicolumn{6}{|c|}{ Selected Area Edit Options } \\
\hline Add Constant ... & Multiply Factor ... & SetValues... & Replace... & \multicolumn{2}{|l|}{ Reduce to $\mathrm{LCh} R \ldots$} \\
\hline River Station & Frctn $(n / K)$ & $n \# 1$ & $\mathrm{n} \# 2$ & $n \# 3$ & $\Delta$ \\
\hline 571633.928 & n & 0.045 & 0.045 & 0.045 & \\
\hline \begin{tabular}{|l|l|}
58 & 1599.646 \\
\end{tabular} & $n$ & 0.045 & 0.045 & 0.045 & \\
\hline \begin{tabular}{|l|l|}
59 & 1545.721 \\
\end{tabular} & $n$ & 0.045 & 0.045 & 0.045 & \\
\hline 601486.538 & $n$ & 0.045 & 0.045 & 0.045 & \\
\hline $61 \quad 1420.825$ & In & 0.055 & 0.07 & 0.055 & \\
\hline 621281.235 & $n$ & 0.055 & 0.07 & 0.055 & \\
\hline \begin{tabular}{|l|l|}
63 & 1181.984
\end{tabular} & $n$ & 0.055 & 0.07 & 0.055 & \\
\hline \begin{tabular}{|l|l|}
64 & 1131.776 \\
\end{tabular} & $n$ & 0.055 & 0.07 & 0.055 & \\
\hline $\begin{array}{ll}65 & 1059.129\end{array}$ & $n$ & 0.055 & 0.07 & 0.055 & \\
\hline \begin{tabular}{|l|l}
66 & 1005.931
\end{tabular} & $n$ & 0.055 & 0.07 & 0.055 & \\
\hline \begin{tabular}{|l|l|}
628.1494 \\
\end{tabular} & $n$ & 0.055 & 0.07 & 0.055 & \\
\hline \begin{tabular}{|l|l|}
646.2893 \\
\end{tabular} & $n$ & 0.055 & 0.07 & 0.055 & \\
\hline 69801.0588 & $n$ & 0.055 & 0.07 & 0.055 & -1 \\
\hline OK & & Cancel & & Help & \\
\hline
\end{tabular}

Fig. 14. Edit Manning's n value

The spread and maximum water levels of floods in the area in 50, 100, 500 and 1000-year return intervals have been determined using the 1D HEC-RAS Hydraulic 
model. The final result was a flood inundation map that clearly shows the spatial extent of the flooded area along part of Corbu Creek and lower elevation areas within the catchment.

\section{RESULTS OBTAINED}

The results consist of: elevation of the free surface of water, average velocity, depths and are they are presented graphically and tabulated. The essential output of HEC-RAS is the water elevation at each cross section at a given flow rate. The results of multiple flow rate simulations can be included in a single output file. The HECRAS output is shown below.

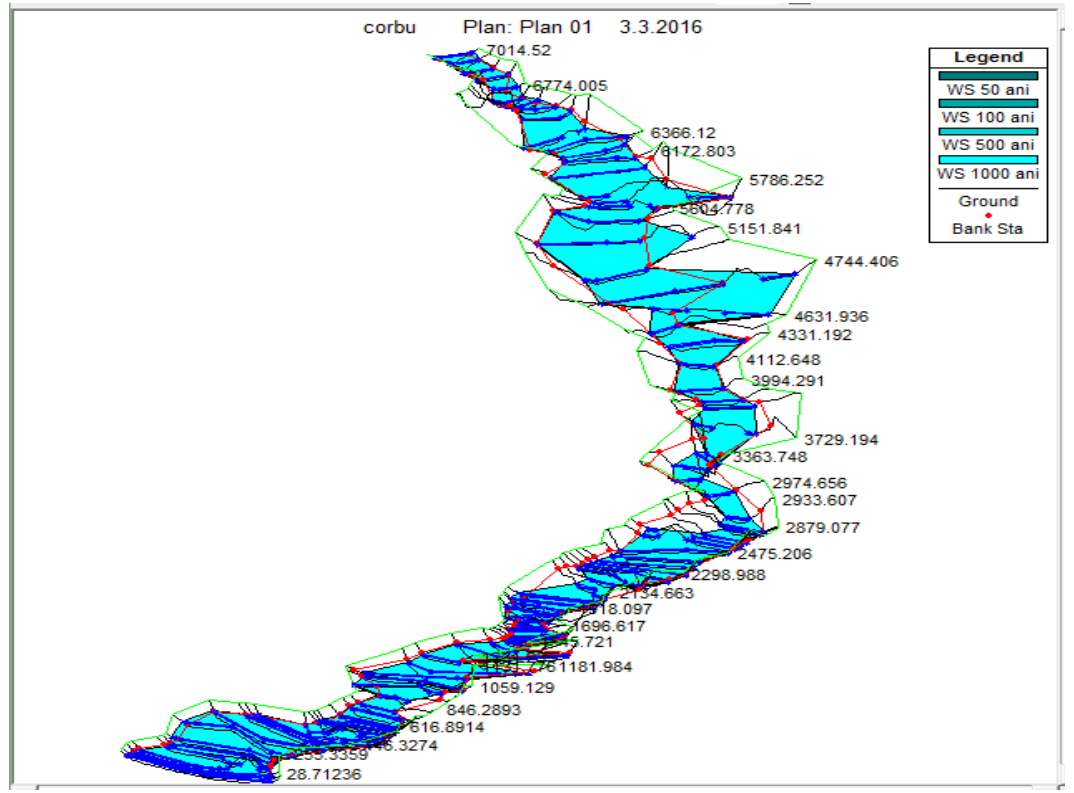

Fig. 15. HEC-RAS output, showing water surface elevations for different flowrate

The mapping of the flooding limits is done by intersecting the plan of the free surface of water with the numerical model of the land. The polygon representing the flood prone areas can be saved as a shape file or other formats and can be overlapped over any plan. Using the Water Surface Generation function found in RAS Mapping/Inundation Mapping section and choosing the profile with the desired flow, one flood hazard map can be created for each flow, and by overlaying the flood over the topographic map, a flood risk.map is obtained. Figure 16 illustrates the flood limits at a exceedance probability $\mathrm{p}=0.1 \%$ (return period $=1000$ years) 


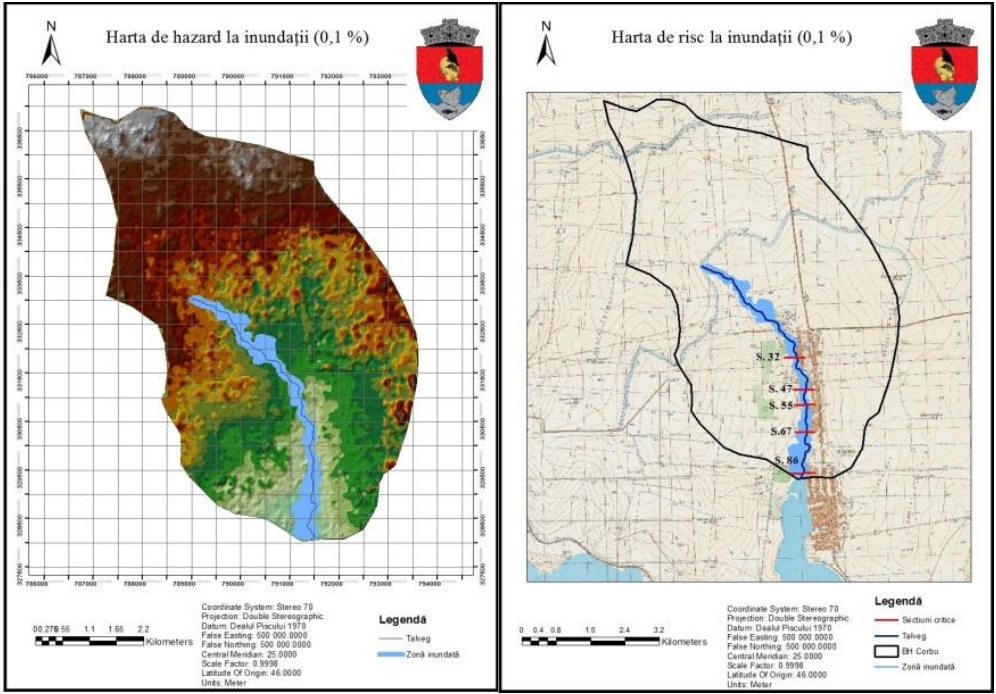

Fig. 16. Flood hazard map (left) and Flood risk map (right) for $p=0.1 \%$

From measurements on the flood risk map (Fig. 16) it appears that the flooded area extends up to $30577 \mathrm{~m} 2$ for the probability of $0.1 \%$. We have detected zones in the studied area where the water level exceeds the critical safety level for which cross sections were extracted through the riverbed and at the same time they were marked on the flood risk map (with red colour).
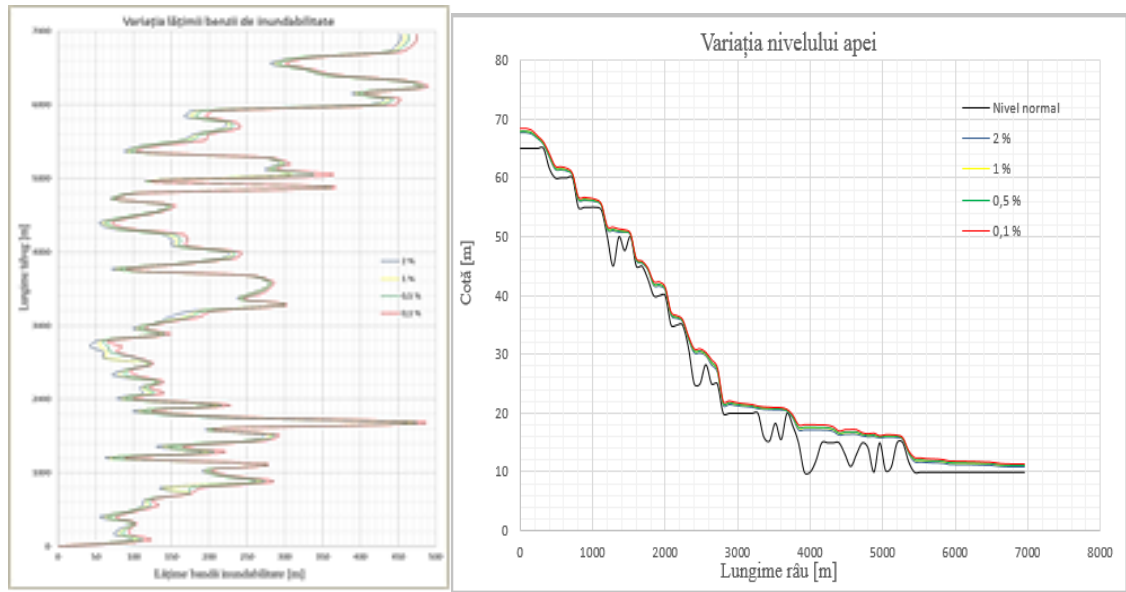

Fig. 17. The flood inundation limits variation (left) and water level variation on profile (right) 
The value of the surface water volume varies between $25000 \mathrm{~m} 3$ for the probability of $2 \%$ and $54000 \mathrm{~m} 3$ for the probability of $0.1 \%$. The results obtained make us to a risk level assessment for the inhabitants of the locality as a result of the increase of the water level above the critical level and the proposal of measures for its removal.

\section{CONCLUSION}

A hydraulic model was used to simulate flash flood inundation in a small drainage basin induced by storm rainfalls in the Corbu lowland area, Constanta County. Thus, starting from a real intense rainfall event and a series of hydrological data recorded at the gauging station in the studied area and their processing by statistical methods, the flows are obtained with different probabilities of occurrence.

Using the HEC RAS program, a one-dimensional hydrodynamic model for determining flash flood prone areas, flood inundation limits were obtained by hydraulic calculations based on the resulting flows. HEC RAS, was used to calculate single water surface elevations for a number of cross sections along the Corbu creek and to calculate the respective flood parameters. The results were compared to actual data recorder during various flooding events in the Corbu drainage basin.

Using ArcGIS 10.1 program, a spatial analysis of the studied area was performed. With the help of HEC GeoRAS extension, it was possible to link the two programs mentioned above, and by overlaying the obtained results, different maps such as flood hazard maps were obtained.

The measurement undertaken in the field immediately after the inundation correspond with the information provided by the flash flood simulation with the hydraulic model. The most affected areas of Corbu locality were the center lowland area.

Following the above-mentioned steps, a temporal and spatial risk assessment of flood hazards in a small river drainage basin, or in a given area or even in an isolated sector (river sector) can be made by analysing the hydrographical network and the spatial framework in which it is taking place. In order to obtain results as close as possible to the real situation, with minimal errors, it is necessary to calibrate the different input data by making direct measurements on the terrain, results that lead to an analysis of the affected area at flooded household level.

The hydraulic model developed using the HEC-RAS software was used to generate flash flooding maps in the area crossed by the Corbu Creek, based on which the flood protection system can be improved and early flash flood warning systems need to be implemented in all regions that are prone to such floods.

Such flash flood hazard and risk maps are generated with aims to: identify areas where there is a risk of flooding, flood hazard regionalization, determining vulnerability to flooding in areas with a high flood risk, establishing the flooding causes and describing the anthropogenic factors contributing to the worsening of the flooding phenomenon, estimation of trends in the occurrence of future floods, the presentation of measures and actions needed to reduce the flooding risks, planning 
various categories of works to protect infrastructure and areas which may be affected by any possible flood. Knowing the rainfall flow parameters water velocities, the concentration time, the routes that direct this flow to the river bed, the level that water can reach in different sections, the surfaces and targets affected by the water level increase, an analysis can be made of the potential flash flood inundation risk to which the area under study may be exposed. In this case, the authorities in charge with the plan for prevention, protection and mitigation of floods management[7], [8], could carrying out a rapid analysis of the potential risk to the area and may organize in due time the necessary measures and intervention during the flash flood phenomenon.

\section{ACKNOWLEDGEMENTS}

The authors would like to thank Emanuel Ionuț Coleși for his assistance with the preparation of the figures for this paper.

\section{REFERENCES}

[1] Maftei C., Papatheodorou K., Flash Flood Prone Area Assessment Using Geomorphological and Hydraulic Model. J Environ Prot Ecol, 16 (1), 63 (2015);

[2] Sârbu, D. - A Mathematical Model Used to Simulate Floods on The Racu Brook, Ovidius University Annals of Constanta-Series Civil Engineering, Year XIV - Nr. 15, ISSN-1584-5990, pp. 257 - 264, Constanța, 2013;

[3] US Army Corps of Engineers, HEC-RAS River Analysis System. User's Manual, USA, Hydrologic Engineering Center http://www.hec.usace.army.mil/software/ hecras/documentation/ HECRAS_4.1_Users_Manual.pdf, 2010a;

[4] US Army Corps of Engineers, HEC-RAS River Analysis System, Hydraulic Reference Manual, Hydrologic Engineering Center, USA. http://www.hec.usace.army.mil/software/hecras/documentation/HECRAS_4.1_

Reference_Manual.pdf, 2010b;

[5] US Army Corps of Engineers, HEC-RAS River Analysis System. Application Guide. Hydrologic Engineering Center USA. http://www.hec.usace.army.mil/ software/hecras/documentation/HEC-RAS_4.1_Applications_Guide.pdf, 2010c; [6] US Army Corps of Engineers, HEC-GeoRAS/GIS Tools for Support of HEC-RAS using ArcGIS. User's Manual, Hydrologyc Engineering Center, USA, http://www.hec.usace.army.mil/software/hecgeoras/documentation/HECGeoRAS42_ Users Manual.pdf, 2010d;

[7]*** Administrația Bazinală de Apă Dobrogea-Litoral, - Planul de management al riscului la inundații, 2015, 2016;

[8]*** Administrația Bazinală de Apă Dobrogea-Litoral - Planul pentru prevenirea, protecția și diminuarea efectelor inundațiilor, scenarii de amenajare și priorizare în spațiul hidrografic Dobrogea litoral,Versiunea 3, 2012;

[9]*** Environmental Systems Research Institute - ESRI, ArcGIS 10.1, Help documentation, [http://help.arcgis.com/en/arcgisdesktop/ 10.1/help/index.html, 2010; 
[10]*** European Parliament, Council: Directive 2007/60/EC on the assessment and management of flood risks, Official Journal of the European Union, L288, pp 27-34, 2007;

[11]*** H.G. nr. 565/2013 privind modul de elaborare si conţinutul hărţilor de hazard la inundații si al hărţilor de risc la inundaţii, 2013;

[12]*** I.N.H.G.A - Studii necesare implementării Directivei 2007/60/CE privind evaluarea și gestionarea riscurilor la inundații 